\title{
De zonevreemde bedrijvenproblematiek in Vlaanderen
}

Citation for published version (APA):

Braeckman, G., \& Vanhaverbeke, W. P. M. (1999). De zonevreemde bedrijvenproblematiek in Vlaanderen. NIBOR, Netherlands Institute of Business Organization and Strategy Research. NIBOR Research Memorandum No. 02 https://doi.org/10.26481/umanib.1999002

Document status and date:

Published: 01/01/1999

DOI:

10.26481/umanib.1999002

Document Version:

Publisher's PDF, also known as Version of record

\section{Please check the document version of this publication:}

- A submitted manuscript is the version of the article upon submission and before peer-review. There can be important differences between the submitted version and the official published version of record.

People interested in the research are advised to contact the author for the final version of the publication, or visit the DOI to the publisher's website.

- The final author version and the galley proof are versions of the publication after peer review.

- The final published version features the final layout of the paper including the volume, issue and page numbers.

Link to publication

\footnotetext{
General rights rights.

- You may freely distribute the URL identifying the publication in the public portal. please follow below link for the End User Agreement:

www.umlib.nl/taverne-license

Take down policy

If you believe that this document breaches copyright please contact us at:

repository@maastrichtuniversity.nl

providing details and we will investigate your claim.
}

Copyright and moral rights for the publications made accessible in the public portal are retained by the authors and/or other copyright owners and it is a condition of accessing publications that users recognise and abide by the legal requirements associated with these

- Users may download and print one copy of any publication from the public portal for the purpose of private study or research.

- You may not further distribute the material or use it for any profit-making activity or commercial gain

If the publication is distributed under the terms of Article $25 \mathrm{fa}$ of the Dutch Copyright Act, indicated by the "Taverne" license above, 


\title{
De zonevreemde bedrijvenproblematiek in Vlaanderen
}

\author{
Guy Braeckman ${ }^{1}$ en Wim Vanhaverbeke ${ }^{2}$
}

Januari 1999

\begin{abstract}
De zonevreemde bedrijven vormen in Vlaanderen een belangrijk probleem binnen de huidige ruimtelijke planning. Zonevreemde bedrijven hebben niet alleen een ruimtelijke component (ze zijn zonevreemd) maar ook een economische component (het zijn bedrijven). Een realistische oplossing voor deze problematiek zal bijgevolg niet alleen ruimtelijke maar ook sociale en economische overwegingen in acht moeten nemen. De economische effecten van beleidsmaatregelen over de uitbreidingsmogelijkheden van zonevreemde bedrijven kunnen maar ingeschat worden als er een adequaat beeld bestaat van het aantal zonevreemde bedrijven en hun economisch belang. Daarenboven kan er voor de zonevreemde bedrijven geen algemene, abstracte oplossing geboden worden: deze bedrijven zijn altijd ingebed in een specifieke streekeconomie - die sterk kan verschillen van die van andere regio's; ze dienen dan ook vanuit die specifieke context beoordeeld te worden. Dit vraagt op zijn beurt om een nieuwe invulling van de relatie tussen lokale en centrale overheden: een centralistische, doctrinaire en louter planologische aanpak zal systematisch te kort schieten in het formuleren van werkbare oplossingen.
\end{abstract}

\section{Inleiding}

De "zonevreemde bedrijven "-problematiek is niet meer weg te branden uit de actualiteit. Sinds de publicatie van het Ruimtelijk Structuurplan Vlaanderen en de omzendbrief 97/01 is de hernieuwde aandacht algemeen.

Het meest triviale dat men kan zeggen over deze problematiek is dat ze zich situeert op de snijlijn van economie en ruimtelijke ordening. Dit heeft evenwel heel wat implicaties. Door het feit dat het om bedrijven gaat is het logisch om bij het bepalen van de uitbreidingsmogelijkheden uit te gaan van de sociaal-economische betekenis van ieder zonevreemd bedrijf. Een eenzijdige ruimtelijke afweging zal op termijn significante welvaartschadende effecten hebben omdat men geen rekening houdt met de eigen sociale en economische dynamiek van deze bedrijven.

Voor zonevreemde bedrijven kan er ook geen algemene, abstracte oplossing geboden worden zonder voldoende gedetailleerde kennis van de ruimtelijke realiteit. Iedere top down benadering moet getoetst kunnen worden aan de specifieke bottom-up informatie vanuit de lokale praktijk. Dit vraagt op zijn beurt om het uitbouwen van een modern overlegsysteem tussen de lokale en centrale overheden op basis van overleg, verantwoordelijkheidszin, wederzijds respect en subsidiariteit. 
Daarenboven zijn zonevreemde bedrijven altijd ingebed in een specifieke streekeconomie die sterk kan verschillen van die in andere regio 's. Zonevreemde bedrijven zullen daarom niet overal in Vlaanderen hetzelfde economisch belang hebben en dezelfde rol spelen binnen de streekeconomie. Daarnaast bestaat er reeds voldoende empirische evidentie om te besluiten dat de zonevreemde problematiek ook verschilt van gemeente tot gemeente binnen eenzelfde subregio. Vooral de verschillen tussen landelijke en stedelijke gebieden zijn zeker belangrijk. Uitbreidingsmogelijkheden voor zonevreemde bedrijven dienen dan ook altijd vanuit die specifieke ruimtelijk-economische context beoordeeld te worden.

Het is tenslotte merkwaardig dat de bevoegde Minister zich reeds heeft uitgesproken over de uitbreidingsmogelijkheden van 52 bedrijven in twee West-Vlaamse gemeenten terwijl men nog geen enkel wetenschappelijk onderbouwd idee heeft over het aantal zonevreemde bedrijven in Vlaanderen en over hun economisch belang. Het bepalen van uitbreidingsmogelijkheden van zonevreemde bedrijven kan men niet los zien van het economisch gewicht van deze bedrijven in de Vlaamse economie. De eerste empirische gegevens wijzen uit dat het gaat om vele duizenden bedrijven met een gezamenlijke tewerkstelling tussen de 90.000 en 180.000 jobs. Indien deze schattingen kloppen kan het ruimtelijk beleid niet restrictief optreden zonder de economische dynamiek van een significant deel van de economie aan te tasten. Meer duidelijkheid over het aantal zonevreemde bedrijven is dus een absolute prioriteit.

Het artikel is als volgt ingedeeld. Eerst gaan we in op de plaats van de zonevreemdheid' binnen de planningscontext. Vervolgens vatten we de resultaten samen van enkele studies over het economisch belang van zonevreemde bedrijven. Daarna wordt nagegaan hoe de houding van de overheid t.o.v. zonevreemde bedrijven was gedurende de laatste twee decennia. Vervolgens wordt het huidig ruimtelijk ordeningsbeleid t.a.v. zonevreemde bedrijven doorgelicht. Vooraleer afgesloten wordt met een concluderend deel wordt nog even ingegaan op de gevalstudie van de gemeente Wingene.

\section{Zonevreemdheid - ontstaan}

Zonevreemdheid houdt verband met de plannen van aanleg zoals ze voorzien zijn in het decreet betreffende de ruimtelijke ordening, gecoördineerd op 22 oktober 1996 (DRO). Plannen van aanleg zijn de neerslag van een ruimtelijk bestemmingsconcept, dat niet steeds de bestaande feitelijke toestand overneemt. Onder de uniforme bestemming van het aanlegplan is een gedifferentieerde complexe maatschappelijke werkelijkheid aanwezig met een eigen ruimtelijke veruitwendiging. Het planconcept streeft naar een uniform gereduceerd ruimtelijk eindbeeld zonder voldoende rekening te kunnen houden met de bestaande maatschappelijke dynamiek aanwezig in het gebied. Die dynamiek heeft een eigen ruimtelijke agenda. Ofwel vanuit de reeds bestaande toestand, ofwel vanuit ontwikkelingen waarmee bij de planopmaak geen rekening werd gehouden. Het is dit spanningsveld, deze discrepantie tussen de bestaande stedenbouwkundige toestand en de in het aanlegplan vastgelegde eindbestemming die aanleiding geeft tot zonevreemdheid.

Zonevreemdheid binnen de planningscontext heeft alles te maken met de decretale regeling ter zake en de manier waarop de overheid hieraan invulling heeft gegeven. Het is dus noodzakelijk enkele essentiële punten hiervan te duiden. 
Vooreerst worden plannen van aanleg in Vlaanderen op twee niveaus opgemaakt, namelijk op het niveau van het gewest, de gewestplannen, en op het niveau van de gemeenten, de algemene en bijzondere plannen van aanleg.

Tot de verplichte inhoud van de gewestplannen behoort de aanduiding van de bestaande toestand en de maatregelen van aanleg vereist om te voldoen aan de economische en sociale behoeften van het gewest en ter verbetering van het net der voornaamste verkeerswegen. Tot de verplichte inhoud van de algemene en bijzonder plannen van aanleg behoort de bestaande toestand en respectievelijk de algemene bestemming (APA) en de gedetailleerde bestemming (BPA) van de verschillende delen van het grondgebied voor bewoning, nijverheid, landbouw of enig ander grondgebruik.

In de opvatting van de decreetgever krijgt ieder niveau een specifieke opdracht bij de uitwerking van zijn aanlegplannen: het Gewest neemt in zijn gewestplannen de maatregelen van aanleg opterwijl de gemeente in haar gemeentelijke plannen van aanleg zich toelegt op de bestemming van de verschillende gebieden.

In werkelijkheid is het enigszins anders gelopen. Bij de facultatieve inhoud van een gewestplan wordt in het DRO bepaald dat een gewestplan ook geheel of ten dele die zaken die in een gemeentelijk algemeen plan zijn opgenomen kan bevatten. Op basis van die bepaling werden de gewestplannen opgemaakt als effectieve bestemmingsplannen. Als uitvoeringsinstrumenten van het gewestelijk beleid hebben de gewestplannen zich hoofdzakelijk op het inhoudelijk niveau van de algemene plannen van aanleg ontwikkeld. Zij geven voor gans Vlaanderen de algemene bestemming van de verschillende delen van het grondgebied weer. Ze zijn verworden tot gedetailleerde bodembestemmingsplannen op het niveau van het individuele perceel. Vanuit die detaillering verliezen ze hun dimensie van vertolker van het beleid van het gewest, en bevinden ze zich veeleer op het niveau van een detailordening die thuishoort op het gemeentelijk niveau. Ook naar effectieve invulling toe overstijgt dergelijke benadering de planningscapaciteit die op het niveau van het gewest aanwezig is. Ordening op niveau van percelen is niet te vatten in een gewestelijk planningsproces; op dit niveau is het onmogelijk om met de gedifferentieerdheid, de eigenheid van de lokale situatie rekening te houden. In dergelijke situatie is het evident dat er discrepanties bestaan tussen de feitelijke situatie op het terrein en de conceptuele bestemmingsvertolking van het aanlegplan.

Een tweede belangrijk punt is dat alle plannen van aanleg in het DRO verordenende kracht hebben. Deze bepaling is essentieel en geeft aan de plannen van aanleg een grote draagwijdte. Het betekent immers dat iedere overheid in haar beslissingen gehouden is rekening te houden met de bepalingen van de plannen van aanleg. Dus niet alleen de overheid die beslissingen neemt in uitvoering van het DRO, maar ook de overheid die bijvoorbeeld in uitvoering van het milieuvergunningendecreet een beslissing neemt over een aanvraag tot het bekomen van een milieuvergunning. Ook de overheid die beslist in uitvoering van een andere wetgeving is gehouden de voorschriften van de plannen van aanleg in acht te nemen.

Door de algemene gelding van de gewestplannen en hun hierboven beschreven bodembestemmend karakter tot op het niveau van het gebruik van het individuele perceel, is het duidelijk dat zij een enorme impact hebben op de ontwikkelingen van een gebied. Het is daarenboven een conserverende impact, aangezien de vastgelegde bestemmingen van toepassing blijven tot ze, na een herziening van het aanlegplan, vervangen zijn door nieuwe bestemmingen. 
Als instrumenten van het Gewest, met een ordenend karakter tot op de microschaal van het individuele perceel, krijgen ze vanuit hun inhoud en hun juridische betekenis een statisch karakter. Waar bij de opmaak mag verwacht worden dat ze nog enigszins aansluiting vinden met de globale ruimtelijk-maatschappelijke behoeften, zullen ze in een dynamische, snel veranderende omgeving al gauw onaangepaste ruimtetoebedelingen handhaven door de grenzen aan de planningscapaciteit die op het gewestelijk niveau aanwezig is.

Een derde fundamenteel principe dat verankerd is in het DRO bepaalt dat van de voorschriften van de aanlegplannen slechts kan afgeweken worden in de gevallen en in de vormen door de wet bepaald. Soepelheid ten aanzien van de voorzieningen van de aanlegplannen vloeit dus voort ofwel uit de soepelheid van de in het plan zelf opgenomen voorschriften ofwel uit de afwijkingsmogelijkheden die door het DRO zijn toegelaten.

Waar zonevreemdheid betrekking heeft op de discrepantie tussen werkelijkheid en concept zal zij bij haar ruimtelijke ontwikkelingsmogelijkheden beroep moeten kunnen doen op die soepelheid. De zich over de jaren heen wijzigende houding van de overheid ten aanzien van die soepelheid maakt dat "zonevreemdheid" in een spiraal van onzekerheid is terechtgekomen en vanuit die positie nog steeds om een fundamentele oplossing vraagt. De wijze waarop met dit probleem kan omgegaan worden raakt aan het fundamenteel debat rond rol en de positie van ruimtelijke ordening in het oplossen van maatschappelijke problemen (SERV, 1998a, 1998b). Vooraleer hierop dieper in te gaan lijkt een cijfermatige duiding van de problematiek niet onbelangrijk.

\section{Zonevreemdheid: een kwantitatieve benadering}

Zonevreemde bedrijven vormen een thema waar ruimtelijke ordening in het algemeen of structuurplanning in het bijzonder en de economische ontwikkeling van sub-regio's met elkaar vervlochten zijn. Een structuurplanning die enkel werkt op basis van ruimtelijke uitgangspunten loopt het gevaar geen rekening te houden met de mogelijke negatieve economische gevolgen van deze aanpak. Vooral wanneer er veel zonevreemde bedrijven zijn en een significant deel van de sub-regionale economie steunt op deze bedrijven, zou een eenzijdige ruimtelijke benadering van de zonevreemde bedrijven kunnen leiden tot de ontwrichting van de economische dynamiek.

In deze sectie gaan we vervolgens in op het economisch belang van deze bedrijven en de onderlinge verschillen tussen de gemeenten.

\subsection{Het economisch belang van de zonevreemde bedrijven}

Het belangrijkste probleem is dat niemand zicht heeft op het economisch belang van zonevreemde bedrijven in Vlaanderen. In het RSV (Ruimtelijke Structuurplan Vlaanderen,1998, deel 1A, p. 159) wordt toegegeven dat er over de omvang van de zonevreemde bedrijvigheid weinig of niets bekend is. Tot op heden zijn alleen voor zuid en midden West-Vlaanderen, het arrondissement Dendermonde en een paar gemeenten zoals Puurs en Mechelen een aantal studies verricht. Scheers en Meuris (1997) beperken zich in een studie voor de arrondissementen Kortrijk, Roeselare en Tielt tot de zonevreemde bedrijven in het agrarisch gebied en het woongebied met landelijk karakter. Hun resultaten zijn samengevat in de volgende tabel. 
Tabel 1: Zonevreemde bedrijvigheid in Zuid en Midden West-Vlaanderen

\begin{tabular}{|c|c|c|c|}
\hline Gemeente & $\begin{array}{l}\text { Aantal bedrijven } \\
\text { Volgens NBB }\end{array}$ & $\begin{array}{l}\text { Aantal zonevreemde } \\
\text { Bedrijven }\end{array}$ & Aandeel \\
\hline \multicolumn{4}{|c|}{$\begin{array}{l}\text { Zonevreemde bedrijven in het arrondissement Kortrijk } \\
\text { a.v. het agrarisch gebied en woongebied met landelijk karakter }\end{array}$} \\
\hline $\begin{array}{l}\text { Anzegem } \\
\text { Avelgem } \\
\text { Deerlijk } \\
\text { Harelbeke } \\
\text { Kortrijk } \\
\text { Kuurne } \\
\text { Lendelede } \\
\text { Menen } \\
\text { Spiere-Helkijn } \\
\text { Waregem } \\
\text { Wevelgem } \\
\text { Zwevegem }\end{array}$ & $\begin{array}{l}338 \\
147 \\
398 \\
719 \\
2547 \\
414 \\
152 \\
593 \\
41 \\
1201 \\
853 \\
412\end{array}$ & $\begin{array}{l}166 \\
20 \\
49 \\
80 \\
181 \\
7 \\
17 \\
24 \\
5 \\
126 \\
51 \\
101\end{array}$ & $\begin{array}{l}49 \% \\
14 \% \\
12 \% \\
11 \% \\
7 \% \\
2 \% \\
11 \% \\
4 \% \\
12 \% \\
10 \% \\
6 \% \\
25 \%\end{array}$ \\
\hline Totaal & 7815 & 827 & $11 \%$ \\
\hline \multicolumn{4}{|c|}{$\begin{array}{l}\text { Zonevreemde bedrijven in het arrondissement Roeselare } \\
\text { t.a.v. het agrarisch gebied en woongebied met landelijk karakter }\end{array}$} \\
\hline \begin{tabular}{|l|} 
Hooglede \\
Ingelmunster \\
Izegem \\
Ledegem \\
Lichtervelde \\
Moorslede \\
Roeselare \\
Staden
\end{tabular} & $\begin{array}{l}193 \\
292 \\
807 \\
203 \\
140 \\
224 \\
1532 \\
211\end{array}$ & $\begin{array}{l}91 \\
72 \\
90 \\
60 \\
53 \\
61 \\
200 \\
52\end{array}$ & $\begin{array}{l}47 \% \\
25 \% \\
11 \% \\
30 \% \\
38 \% \\
27 \% \\
13 \% \\
25 \%\end{array}$ \\
\hline Totaal & 3602 & 679 & $19 \%$ \\
\hline \multicolumn{4}{|c|}{$\begin{array}{l}\text { Zonevreemde bedrijven in het arrondissement Tielt } \\
\text { net agrarisch gebied en woongebied met landelijk karakter }\end{array}$} \\
\hline Ardooie & 265 & 114 & $43 \%$ \\
\hline Dentergem & 186 & 82 & $44 \%$ \\
\hline Meulebeke & 284 & 128 & $45 \%$ \\
\hline Oostrozebeke & 221 & 96 & $43 \%$ \\
\hline Pittem & 174 & 76 & $44 \%$ \\
\hline Ruiselede & 101 & 43 & $43 \%$ \\
\hline Tielt & 497 & 105 & $21 \%$ \\
\hline Wielsbeke & 279 & 19 & $7 \%$ \\
\hline Wingene & 309 & 115 & $37 \%$ \\
\hline \begin{tabular}{|l|} 
Totaal \\
\end{tabular} & 2316 & 778 & $34 \%$ \\
\hline
\end{tabular}

Bron: Scheers, J. en F. Meuris (1997)

De auteurs vinden dat $11 \%$ van de bedrijven in het arrondissement Kortrijk zonevreemd zijn, in het arrondissement Roeselare is dit $19 \%$ en in Tielt 34\%. Deze cijfers geven slechts een deel van de problematiek weer, omdat enkel de bedrijven werden onderzocht die opgenomen zijn in de balanscentrale van de Nationale Bank. Daarenboven werd de zonevreemdheid alleen ten aanzien van het agrarisch gebied en het woongebied met landelijk karakter 
geanalyseerd. Dit houdt in dat de zonevreemde bedrijvigheid in verstedelijkte gebieden erg onderschat wordt: de $11 \%$ voor het arrondissement Kortrijk in de bovenstaande tabel moet daarom sterk gerelativeerd worden. Volgens de inventaris van alle bedrijfsgebouwen met een oppervlakte van meer dan $300 \mathrm{~m}^{2}$, opgemaakt door Leiedal voor het arrondissement Kortrijk, is $32.8 \%$ van de bedrijfsgebouwen gelokaliseerd op industriegebieden, $55.8 \%$ in woongebieden en $11.4 \%$ in de open ruimte. In verstedelijkte gebieden concentreert de zonevreemde bedrijvigheid zich meer -hoe kan het ook anders -in woonzones. Ook deze, in woonzones gelegen bedrijven moeten opgenomen worden in de statistieken omdat uitbreidingsproblemen en de herlokalisatieproblematiek zich ook evengoed daar afspeelt. De reeds decennia aan de gang zijnde uittocht van in stadscentra gelegen bedrijven naar nabijgelegen bedrijventerreinen is het bewijs dat de spontane herlokalisatie van bedrijven uit woonzones op zijn minst evenveel aandacht verdient als de bedrijven die bijvoorbeeld in landbouwzones gelokaliseerd zijn.

Uit twee andere studies over het economisch belang van de zonevreemde bedrijven in de arrondissementen Roeselare-Tielt en Dendermonde (Vanhaverbeke, 1997a, 1998) komen de volgende resultaten met betrekking tot bedrijven met een omzet groter dan 25 miljoen BEF.

Tabel 2: Belang van de zonevreemde bedrijvigheid bij bedrijven met een omzet $>25$ mio $\underline{B E F}$

\begin{tabular}{|l|c|c|c|c|}
\hline \multicolumn{1}{|c|}{ Bedrijfscategorie } & \multicolumn{2}{c|}{$\begin{array}{c}\text { Arrondissementen } \\
\text { Roeselare en Tielt }\end{array}$} & \multicolumn{2}{c|}{$\begin{array}{c}\text { Arrondissement } \\
\text { Dendermonde }\end{array}$} \\
\hline Zonevreemd & $48.1 \%$ & 361 & $38.4 \%$ & 194 \\
\hline Speciaal daartoe opgemaakt BPA & $7.9 \%$ & 59 & $3.0 \%$ & 15 \\
\hline Zone-eigen & $44.1 \%$ & 331 & $58.6 \%$ & 296 \\
\hline
\end{tabular}

Bronnen: Vanhaverbeke (1997a, 1998)

Noot: In de studie voor het arrondissement Dendermonde is de definitie van zonevreemde bedrijven strikter geïnterpreteerd dan in de studie voor de arrondissementen Roeselare-Tielt. Dit kan voor een deel het verschil in resultaten verklaren.

Tabel 3: Economisch belang van de zonevreemde bedrijvigheid bij bedrijven met een omzet $>25$ mio $\underline{B E F}$

\begin{tabular}{|l|c|c|c|c|}
\hline \multicolumn{1}{c|}{$\begin{array}{c}\text { Aandeel van de } \\
\text { zonevreemde bedrijven }\end{array}$} & \multicolumn{2}{c|}{$\begin{array}{c}\text { Arrondissementen } \\
\text { Roeselare en Tielt }\end{array}$} & \multicolumn{2}{c|}{$\begin{array}{c}\text { Arrondissement } \\
\text { Dendermonde }\end{array}$} \\
\hline Tewerkstelling & $32.7 \%$ & 8276 jobs & $28.7 \%$ & 4084 jobs \\
\hline Toegevoegde waarde & $27.5 \%$ & $15.0 \mathrm{mia} \mathrm{BEF}$ & $25.2 \%$ & $7.9 \mathrm{mia} \mathrm{BEF}$ \\
\hline Omzet & $23.1 \%$ & $60.1 \mathrm{mia} \mathrm{BEF}$ & $22.3 \%$ & $22.1 \mathrm{mia} \mathrm{BEF}$ \\
\hline Bedrijfsbelastingen & $27.3 \%$ & $834 \mathrm{mio} \mathrm{BEF}$ & $33.1 \%$ & $525 \mathrm{mio} \mathrm{BEF}$ \\
\hline
\end{tabular}

Bronnen: Vanhaverbeke (1997a, 1998)

Noot: In de studie voor het arrondissement Dendermonde is de definitie van zonevreemde bedrijven strikter geïnterpreteerd dan in de studie voor de arrondissementen Roeselare-Tielt. Dit kan voor een deel het verschil in resultaten verklaren.

De resultaten in de tabellen twee en drie tonen aan dat zonevreemde bedrijvigheid in bepaalde Vlaamse arrondissementen verantwoordelijk is voor een groot deel van de lokale economie. Voor de arrondissementen Roeselare en Tielt komt dit neer op 26.0\% van alle bezoldigde jobs in de industrie en op $11.3 \%$ van de totale tewerkstelling. Voor het arrondissement Dendermonde is dit respectievelijk $23.8 \%$ en $10.0 \%$. 
De resultaten voor het arrondissement Dendermonde zijn interessant omdat soms beweerd wordt dat de zonevreemde bedrijvenproblematiek zich het scherpst stelt in Zuid en Midden West-Vlaanderen omdat dit een aparte economische regio is die zich op basis van endogene groei ontwikkelt (Musyck, 1995; Vanhaverbeke, 1997b). De resultaten voor Dendermonde tonen aan dat zonevreemde bedrijvigheid ook van groot economisch belang is in sub-regio 's buiten West-Vlaanderen. Uit verkennende gesprekken met GOMs, Streekplatformen en de Kamers van Koophandel en Nijverheid blijkt dat de zonevreemde bedrijvenproblematiek belangrijk is in zowat heel Vlaanderen. Alleen in bepaalde delen van de provincie Limburg zou het economisch belang van zonevreemde bedrijven kleiner zijn omdat daar de industrialisatie later en op een meer gestructureerde wijze opgestart is. In de veronderstelling dat de drie geanalyseerde arrondissementen concentratieregio's voor zonevreemde bedrijven zouden zijn, en dat het aantal jobs in deze bedrijven in Vlaanderen niet $10 \%$ maar bijvoorbeeld 5\% zou zijn dan stellen zij in Vlaanderen nog altijd 90.000 mensen aan het werk. Als de drie arrondissementen representatief zouden zijn voor de rest van Vlaanderen dan gaat het om 180.000 jobs. Een meer realistische inschatting zal wellicht tussen deze twee extremen in liggen.

Voor het ogenblik kunnen we alleen maar ruwweg inschatten wat het economisch belang van zonevreemde bedrijven in Vlaanderen is. Zelfs bij de meest voorzichtige schattingen gaat het om vele tienduizenden jobs. Zonevreemde bedrijven zijn economisch dus té belangrijk om ruimtelijke beslissingen te nemen over de uitbreiding en herlokalisatie van deze bedrijven zonder dat men een idee heeft van de economische impact ervan. Het is daarom hoog tijd dat een studie opgestart wordt die een adequate inschatting maakt van het economisch belang van deze bedrijven in Vlaanderen: de methode is op punt gesteld (Scheers en Meuris, 1997) en op een tijdspanne van drie maanden kan een representatieve steekproef van bijvoorbeeld 10.000 bedrijven in Vlaanderen doorgelicht worden. Deze resultaten gekoppeld aan een enquête over de uitbreidings- en herlokalisatiebehoefte (tot 2007) bij de zonevreemde bedrijven binnen deze steekproef zouden een vrij betrouwbare inschatting geven van de zonevreemde bedrijvenproblematiek ${ }^{3}$. Met deze gegevens kan men ook nagaan of de 500 ha die op Vlaams niveau gereserveerd zijn voor het herlokaliseren van zonevreemde bedrijven een realistische inschatting is.

\subsection{Verschillen tussen de gemeenten}

In de vorige sectie is al aangetoond dat er verschillen bestaan tussen de arrondissementen w.b. de zonevreemde bedrijven. In verstedelijkte gebieden ligt een veel groter aandeel van de zonevreemde bedrijven in woonzones. In landelijke gebieden is het aandeel van landbouwzones en woongebieden met landelijk karakter veel groter. Deze verschillen zijn belangrijk omdat de ruimtelijke én economische gevolgen verschillen volgens de bestemmingszones.

Niet alleen subregio 's verschillen van elkaar maar de problematiek verschilt ook duidelijk van gemeente tot gemeente binnen eenzelfde sub-regio. In de volgende twee tabellen zijn de verschillende gemeenten binnen eenzelfde sub-regio samengebracht via een statistische clusteringmethode.

De Intercommunale Vereniging van het land van Waas is voor het ogenblik een enquête aan het afnemen bij alle bedrijven in het arrondissement Sint-Niklaas. Via deze enquête wordt het onder andere mogelijk om een realistische inschatting te hebben van de uitbreidingsbehoeften van de zonevreemde bedrijven en de extra hectaren industriegrond die men moet reserveren voor bedrijven die herlokalisatie binnen de streek overwegen. 
Tabel 4: Verdeling van de gemeenten in de regio Roeselare-Tielt

\begin{tabular}{|c|c|c|c|c|}
\hline & \multicolumn{3}{|c|}{ Aandeel zonevreemde bedrijven } \\
\hline & & $\begin{array}{l}\text { Klein } \\
\text { T: } 20 \% \\
\text { TW: } 15 \% \\
\end{array}$ & \begin{tabular}{|l|} 
Middelmatig \\
T: $41 \%$ \\
TW: $36 \%$ \\
\end{tabular} & \begin{tabular}{|l|} 
Groot \\
T: $59 \%$ \\
TW: $59 \%$ \\
\end{tabular} \\
\hline \multirow{3}{*}{$\begin{array}{l}\text { Aandeel van } \\
\text { zonevreemde } \\
\text { bedrijven in } \\
\text { landbouwzones } \\
\text { op het totaal van } \\
\text { zonevreemde } \\
\text { bedrijven }\end{array}$} & \begin{tabular}{|l|} 
Groot \\
T: $50 \%$ \\
TW: $60 \%$ \\
\end{tabular} & Hooglede $(38,18)$ & $\begin{array}{l}\text { Ardooie }(54,25) \\
\text { Pittem }(28,20)\end{array}$ & Wingene $(41,22)$ \\
\hline & \begin{tabular}{|l|} 
Middelmatig \\
T: $48 \%$ \\
TW: $48 \%$ \\
\end{tabular} & $\begin{array}{l}\text { Wielsbeke }(51,20) \\
\text { Staden }(40,9)\end{array}$ & $\begin{array}{l}\text { Lichtervelde }(21,11) \\
\text { Ledegem }(36,17)\end{array}$ & $\begin{array}{l}\text { Dentergem }(36,24) \\
\text { Meulebeke }(48,31)\end{array}$ \\
\hline & $\begin{array}{l}\text { Klein } \\
\text { T: } 9 \% \\
\text { TW: } 10 \%\end{array}$ & $\begin{array}{l}\text { Tielt }(79,30) \\
\text { Izegem }(129,53)\end{array}$ & \begin{tabular}{|l} 
Ruiselede $(15,8)$ \\
Moorslede $(34,16)$
\end{tabular} & $\begin{array}{l}\text { Ingelmunster }(48,35) \\
\text { Oostrozebeke }(31,25)\end{array}$ \\
\hline
\end{tabular}

Noten: (1) T en TW geven het gemiddelde percentage weer voor de desbetreffende categorie respectievelijk voor de tewerkstelling (T) en de toegevoegde waarde (TW).

(2) De cijfers achter de gemeenten geven het aantal bedrijven weer (links voor de horizontale as, rechts voor de verticale).

Bron: Vanhaverbeke (1997a)

Tabel 5: Verdeling van de gemeenten in het arrondissement Dendermonde

\begin{tabular}{|c|c|c|c|c|}
\hline & \multicolumn{3}{|c|}{ Aandeel zonevreemde bedrijven } \\
\hline & & $\begin{array}{l}\text { Klein } \\
\text { T: } 21 \% \\
\text { TW: } 15 \%\end{array}$ & \begin{tabular}{|l|} 
Middelmatig \\
T: $38 \%$ \\
TW: $39 \%$
\end{tabular} & $\begin{array}{l}\text { Groot } \\
\text { T: } 68 \% \\
\text { TW: } 69 \%\end{array}$ \\
\hline \multirow{3}{*}{\begin{tabular}{|l|} 
Aandeel van \\
zonevreemde \\
bedrijven in \\
landbouwzones \\
en ecologisch \\
waardevolle \\
gebieden op het \\
totaal van \\
zonevreemde \\
bedrijven
\end{tabular}} & \begin{tabular}{|l|} 
Groot \\
T: $71 \%$ \\
TW: $67 \%$ \\
\end{tabular} & & Laarne $(6,5)$ & \\
\hline & $\begin{array}{l}\text { Middelmatig } \\
\text { T: } 26 \% \\
\text { TW: } 38 \%\end{array}$ & & & Waasmunster $(11,5)$ \\
\hline & \begin{tabular}{|l|} 
Klein \\
T: $13 \%$ \\
TW: $15 \%$
\end{tabular} & $\begin{array}{l}\text { Hamme }(30,3) \\
\text { Zele }(25,1) \\
\text { Buggenhout }(10,2) \\
\text { Lebbeke }(22,5)\end{array}$ & $\begin{array}{l}\text { Dendermonde }(46,10) \\
\text { Wetteren }(24,4) \\
\text { Wichelen }(8.4)\end{array}$ & Berlare $(12,1)$ \\
\hline
\end{tabular}

Noten: (1) T en TW geven het gemiddelde percentage weer voor de desbetreffende categorie respectievelijk voor de tewerkstelling (T) en de toegevoegde waarde (TW).

(2) De cijfers achter de gemeenten geven het aantal bedrijven weer (links voor de horizontale as, rechts voor de verticale).

Bron: Vanhaverbeke (1998)

Uit de tabellen is op te maken dat er grote verschillen bestaan in het aandeel van zonevreemde bedrijven in de gemeentelijke economie en het aandeel van landbouwzones binnen het geheel van zonevreemde bedrijven. In de arrondissementen Roeselare en Tielt zijn de verschillen tussen de gemeenten méér uitgesproken dan in het arrondissement Dendermonde waar de landelijke gemeenten Laarne en Waasmunster uit de band springen.

Deze relatief grote verschillen tussen de gemeenten zijn het gevolg van de grootte van de gemeenten, hun graad van verstedelijking, het relatief belang van historisch gegroeide bedrijven en het gevoerde ruimtelijk-economisch beleid gedurende de laatste decennia. De 
betekenis van dit laatste aspect wordt duidelijk geïllustreerd aan de hand van de gemeente Wielsbeke. Wielsbeke is een gemeente met een zeer versnipperde industriële structuur. Nochtans is de problematiek van de zonevreemdheid er relatief gering, omwille van de alertheid van de lokale overheid en de permanente bekommernis om de bedrijven op te nemen in aangepaste bestemmingsgebieden in de plannen van aanleg.

De grote verschillen tussen de gemeenten impliceren dat het ruimtelijk beleid ook best de situatie per gemeente bekijkt en rekening houdt met het lokaal economisch belang van de zonevreemde bedrijven en hun verwevenheid met de streekeconomie.

\section{Zonevreemdheid - houding van de overheid gedurende de laatste 20 jaar}

Als eerste werkhypothese kunnen we zonevreemdheid definiëren als de strijdigheid van een feitelijke toestand, zij het een gebouw, functie of activiteit, met de vastgelegde bestemming in het aanlegplan. Hoe de overheid hiermee is omgesprongen zal blijken uit de soepelheid waarmee ze zich opstelt ten aanzien van deze problematiek.

\subsection{Gewestplannen}

In een eerste periode, gaande van 1972 tot 1984 wordt de soepelheid ten aanzien van de algemene gewestplanvoorschriften gerealiseerd door het opnemen van uitzonderingsbepalingen in de gewestplannen zelf. Voor alle gewestplannen werden de voorschriften vastgelegd in het koninklijk besluit van 28 december 1972 betreffende de inrichting en de toepassing van de ontwerp-gewestplannen en de gewestplannen. Algemeen is dit besluit ingedeeld in drie hoofdstukken, waarbij in hoofdstuk I het toepassinggebied van het besluit zelf geregeld wordt, in hoofdstuk II de bestemming en het gebruik van de grond, en in hoofdstuk III de voorschriften betreffende de toepassing van de ontwerp-gewestplannen en de gewestplannen. In dit laatste hoofdstuk worden de afwijkings-mogelijkheden behandeld. Samengevat kwamen ze neer op:

- de mogelijkheid om voor zaken van algemeen belang af te wijken van de voorgeschreven bestemming (artikel 20 van het $\mathrm{KB}$ );

- de mogelijkheid om voor gebouwen die niet in overeenstemming zijn met de bestemming een vergunning voor verbouwen toe te staan (artikel 21 van het KB);

- de mogelijkheid om voor bestaande inrichtingen een exploitatievergunning in strijd met de bestemming af te leveren voor een bepaalde periode en in afwachting van herlokalisatie (artikel 22 van het $\mathrm{KB}$ );

- de mogelijkheid om binnen een huizengroep nieuwe gebouwen op te richten (artikel 23 van het $\mathrm{KB}$ ).

In 1978 werd het KB van 1972 gewijzigd. Deze wijzigingen hebben slechts een beperkt toepassingsgebied gekend, omdat de bepalingen van dit KB slechts tegenstelbaar waren in die gewestplannen waar ze deel uitmaakten van de procedure die het tot stand komen van het gewestplan bepaalt. De aanpassingen hadden hoofdzakelijk betrekking op de inhoudelijke invulling van de bovenvermelde afwijkingsmogelijkheden.

Een tweede periode vangt aan in 1984. Geconfronteerd met de grenzen die in de voorschriften van de gewestplannen zelf werden ingeschreven, en gelet op de onmogelijkheid om alle gewestplannen te herzien in functie van de reëel voorkomende feitelijke situaties, grijpt de 
decreetgever op een algemene wijze in op de afwijkingsmogelijkheden. Met het "minidecreet" van 1984 wordt een aanpassing aan het DRO doorgevoerd, waarbij het afwijkingsregime ten aanzien van de verordenende voorschriften van de gewestplannen in de regelgeving zelf ingeschreven wordt. Door die regeling kunnen onder andere zonevreemde bedrijven een nieuwe ruimtelijke dynamiek ontplooien. Ze kunnen ver- of herbouwen of uitbreiden, voor zover het maximale volume uitbreiding beperkt blijft tot $100 \%$ van het bestaande volume.

In de loop van de daarop volgende jaren komt de ad hoc besluitvorming in het kader van vergunningen op basis van dit minidecreet meer en meer onder druk te staan. Met het decreet van 23 juni 1993 worden de afwijkingsmogelijkheden op een drastische wijze teruggeschroefd. De zogenaamde opvulregel en de gecreëerde mogelijkheden om te herbouwen worden afgeschaft. De uitbreidingsmogelijkheden worden sterk ingeperkt. Voor bedrijven kunnen ze enkel nog vergund worden voor installaties die het gevolg zijn van milieutechnische eisen. Een economische dynamiek die bijkomende bedrijfsruimte vereist kan niet meer in aanmerking komen voor het afleveren van een bouwvergunning. Wel behouden de bestaande zonevreemde bedrijven hun bestaanrecht, omdat in de decretale regeling wel een mogelijkheid ingebouwd wordt om de nodige milieuvergunningen af te leveren, zelfs al is de exploitatie strijdig met het bestemmingsgebied. In 1994 wordt de in 1993 uitgevaardigde regeling verfijnd met een overgangsregeling. Op dit ogenblik kunnen zonevreemde bedrijven genieten van de volgende afwijkingsmogelijkheden:

\section{1. wat de bouwvergunning betreft:}

- het verbouwen van een bestaand vergund gebouw binnen het bestaande bouwvolume en niet betrekking hebbend op het volledig herbouwen;

- het uitbreiden van een bestaand vergund gebouw met een gebouw of een vaste inrichting op de voorwaarde dat de uitbreiding het noodzakelijk gevolg is van overeenkomstig het decreet van 28 juni 1985 betreffende de milieuvergunning, voorgeschreven algemene, sectorale of bijzondere voorwaarden strekkende tot het bevorderen van de kwaliteit van het leefmilieu;

- het wijzigen van gebruik van een vergund gebouw, voor zover deze wijziging is opgenomen in een door de Vlaamse regering vast te stellen lijst;

2. wat de milieuvergunning betreft:

- het hernieuwen van een milieuvergunning van een inrichting;

- het veranderen van de exploitatie van een inrichting ${ }^{4}$ op voorwaarde dat de verandering geen vermeerdering van de oppervlakte of het volume tot gevolg heeft;

- het exploiteren van een bestaande of nieuwe inrichting waarvoor definitief een bouwvergunning voor het wijzigen van het gebruik van een vergund gebouw is verleend;

- het exploiteren van een bestaande of nieuwe inrichting waarvoor definitief een bouwvergunning voor het verbouwen, herbouwen of uitbreiden van een bedrijfsgebouw met een gebouw of een vaste inrichting is verleend.

Deze afwijkingen kunnen slechts worden verleend op voorwaarde dat de goede ruimtelijke ordening niet wordt geschaad. Dit betekent onder meer dat de ruimtelijke draagkracht van het gebied niet wordt overschreden en dat de voorziene verweving van functies de aanwezige of te

$4 \quad$ Bedoeld zoals in hoofdstuk V van het decreet van 28 juni 1985. 
realiseren bestemmingen in de onmiddellijke omgeving niet in het gedrang brengt of verstoort. Tenslotte werden een aantal gebieden afgebakend waarbinnen de afwijkingsbepalingen niet van toepassing zijn.

Voor bouwvergunningen zijn dit groengebieden, overstromingsgebieden, bosgebieden met ecologische waarde, bufferzones ${ }^{5}$, valleigebieden en agrarische gebieden met ecologisch belang ${ }^{6}$. Voor milieuvergunningen zijn dit een groengebieden, overstromingsgebieden en bosgebieden met ecologische waarde.

Sinds het tot stand komen van de gewestplannen is er dus steeds, binnen bepaalde perken, aanvaard dat er een discrepantie kan zijn tussen de feitelijke aanwezige toestand en de planningsopties. Aan deze "zonevreemde" realiteit werden ontwikkelingsmogelijkheden geboden. Dit was niet eenmalig, maar zelfs in die mate dat aan de dynamiek van die bedrijven ontwikkelingsmogelijkheden ter plaatste gegeven werden (en nog steeds gegeven worden). Blijkbaar waren de afwijkingsmogelijkheden via vergunningen evenwel onvoldoende. Want ook vanuit de planning zelf werd die dynamiek ondersteund. Om dit proces te begrijpen moeten we de betekenis van het BPA ten aanzien van zonevreemdheid bekijken.

\subsection{Bijzondere Plannen van Aanleg}

Bij de behandeling van "zonevreemdheid" in relatie tot het planningsinstrument bijzonder plan van aanleg (BPA) moeten twee invalshoeken belicht worden. Ten eerste moet men zich de vraag stellen wat de gevolgen van "zonevreemdheid"zijn ten aanzien van de inhoud van een BPA, met name ten aanzien van de voorschriften? Ten tweede stelt zich de vraag of het BPA als planningsinstrument gebruikt kan worden om de zonevreemdheid ten aanzien van de gewestplanvoorschriften op te lossen?

\subsubsection{De inhoudelijke dimensie van een BPA}

Ten aanzien van de inhoudelijke dimensie van een BPA is er geen soepelheid voor feitelijke bestemmingsituaties die afwijken van het ontwikkelde planningsconcept. Zonevreemdheid in een BPA krijgt dus geen oplossing met het vergunningenbeleid. Dit volgt enerzijds uit de verplichte inhoud van een BPA en anderzijds uit de beperkte afwijkingsmogelijkheden die in de stedenbouwwet zijn ingeschreven ${ }^{7}$.

$5 \quad$ Zoals bepaald in art 14.4.5. van het koninklijk besluit van 28 december 1972 betreffende de inrichting en de toepassing van de ontwerp-gewestplannen en de gewestplannen tenzij in het geval van de uitbreiding van een bestaand vergund gebouw met uitzondering van de woningbouw in de bouwvergunning een voldoende bufferzone kan worden voorzien in toepassing van art. 7.2.0. van datzelfde koninklijk besluit

6 Voor valleigebieden en agrarische gebieden is dit behoudens die gevallen waarvoor het bestuur Natuurbehoud en -ontwikkeling van AMINAL een gunstig advies verstrekt.

$7 \quad$ Inhoudelijk moet een BPA voldoen aan de bepalingen van artikel 14. Het moet de volgende bepalingen bevatten:

$1^{\circ}$ de bestaande toestand;

$2^{\circ}$ de gedetailleerde bestemming van de in het APA bedoelde gebiedsdelen (zijnde de zones bestemd voor bewoning, nijverheid, landbouw of enig ander grondgebruik);

$3^{\circ}$ het tracé van alle in het verkeerswegennet te brengen wijzigingen;

$4^{\circ}$ de voorschriften betreffende de plaatsing, de grootte en de welstand van gebouwen, afsluitingen, alsmede die betreffende de binnenplaatsen en tuinen.

Het kan bovendien aangeven:

$5^{\circ}$ de voorschriften betreffende het aanleggen en uitrusten van de wegen, de bouwvrije stroken en de beplantingen; 
Door de bepaling dat een BPA enerzijds de gedetailleerde bestemming van de gebiedsdelen moet bevatten, en dat het anderzijds onmogelijk is hierop af te wijken, kan er ten aanzien van de bestemming enkel een strijdigheid met het BPA bestaan. Dergelijke strijdige bestemming is zonder meer ontoelaatbaar. Een probleem van "zonevreemdheid" kan ten aanzien van een BPA enkel tot gevolg hebben dat die functie ofwel moet verdwijnen (zelfs het in stand houden van een strijdige bestemming is binnen het beheersingsgebied van een BPA ontoelaatbaar en kan aanleiding geven tot het vorderen van herstelmaatregelen en strafrechterlijke vervolging), ofwel dat het BPA voor de nieuwe functie moet herzien worden en door een nieuw ordeningsplan vervangen worden.

\subsubsection{Afwijkingsmogelijkheden}

Een BPA is evenwel ook een instrument dat gehanteerd wordt in de problematiek van de zonevreemdheid ten aanzien van een gewestplan. Immers artikel 14 DRO, derde lid, bepaalt: "Wanneer een streek-, gewest- of algemeen plan bestaat, richt het bijzonder plan zich naar de aanwijzingen en bepalingen ervan, en vult ze aan. Het kan er desnoods van afwijken.".

Dit artikel voert dus een afwijkingsmogelijkheid ten aanzien van het gewestplan in, niet met een vergunning, maar met een bijzonder plan van aanleg. Op basis van dit artikel werden BPA's opgemaakt om zonevreemde bedrijven individueel uitbreidingsmogelijkheden te bieden in afwijking van de gewestplanvoorschriften. De ruimte die hier evenwel gegeven wordt, is ingeperkt door het begrip "desnoods afwijken". ${ }^{8}$

$6^{\circ}$ de plaatsen die bestemd worden voor het aanleggen van groene ruimten, bosreservaten, sportvelden en begraafplaatsen, alsmede voor openbare gebouwen en voor monumenten;

$7^{\circ}$ indien een ruilverkaveling of herverkaveling nodig blijkt, de grenzen van de nieuwe kavels, onder vermelding dat die grenzen door het schepencollege kunnen worden gewijzigd met goedkeuring van de Vlaamse regering.

De afwijkingsmogelijkheden voorzien in artikel 49 DRO beperken zich anderzijds tot perceelsafmetingen, afmetingen van de bouwwerken, de plaatsing van de bouwwerken en de voorschriften in verband met het uiterlijk van de bouwwerken.

8 Ten aanzien van deze mogelijkheid komt de afdeling administratie van de Raad van State in haar advies van 22/12/1983 tot de volgende conclusies:

- de voorschriften van een vroeger meer algemeen plan kunnen door de voorschriften van een later meer bijzonder plan van aanleg worden opzijgezet;

- $\quad$ er is een grens aan dit principe, namelijk indien het meer algemene plan niet langer voldoet, wordt het — desgevallend slechts ten dele — herzien;

- $\quad$ slechts wanneer het betrokken gebeid een veeleer klein onderdeel is van het gewestplan, dat kan worden gewijzigd zonder de algemene economie van het gewestplan aan te tasten, kan het meer bijzondere plan er desnoods, dit is zo nodig, van afwijken;

- het oorspronkelijk voorschrift van het vroeger meer algemene plan is ingevolge tijdsverloop voorbijgestreefd of nutteloos geworden en er is behoefte aan een ander voorschrift.

Hieruit besluit de Raad dat een afwijkend plan veronderstelt dat de afwijking steunt op de eigen aard van het betrokken deelgebied, op redenen die specifiek zijn aan dat deelgebied, en die blijken uit de motivering van het afwijkend plan en waarvan de Raad de redelijkheid desgevallend kan toetsen in het kader van het legaliteitsbeginsel.

Hieruit vloeit voort dat:

1) aangezien het afwijkend plan een gemeenteplan betreft, de nood aan nieuwe ordening geografisch duidelijk te lokaliseren is en dat het afwijkend plan niet de algemene economie van het gewestplan mag aantasten. Het gaat om een "detailwijziging".

2) Het afwijkend bijzonder plan een vlugge oplossing wil geven aan een dwingende en nieuwe behoefte aan een afwijkende ordening. 
In haar advies van 22/12/1983 komt de Raad van State tot de conclusie dat het vaststellen en goedkeuren van een B.P.A., dat afwijkt van een vroeger vastgesteld gewestplan, op wettige wijze kan wanneer voldaan is aan de volgende voorwaarden:

- aangetoond is dat de bestemming in het hoger plan achterhaald is (bijvoorbeeld t.g.v. de evolutie van de bevolking, of van de economie) of niet meer verwezenlijkt kan worden;

- de in het lagere plan vooropgestelde bestemming wel beantwoordt aan de op dat ogenblik bestaande planologische noden en mogelijkheden;

- deze planologische redenen duidelijk zijn en goed gelokaliseerd kunnen worden; anders zou misschien veeleer een herziening van het hogere plan aangewezen zijn.

\subsection{Conclusies}

Uit het voorgaande blijkt dat zonevreemdheid enkel een betekenis heeft ten aanzien van de gewestplanbestemmingen. Oplossingen werden in het verleden hoofdzakelijk aangereikt door beslissingen in functie van individuele problemen, ofwel via vergunningen op basis van de toegelaten uitzonderings- of afwijkingsregels, ofwel door het opmaken van een van het gewestplan afwijkend bijzonder plan van aanleg. Niettemin heeft de overheid, door haar welwillende houding de zonevreemdheid telkenmale ontwikkelingskansen ter plaatse geboden. De bedrijven konden in functie van hun feitelijke ligging verder exploiteren en groeien. Slechts waar de beschikbaarheid van ruimte ter plaatse grenzen aan de ontwikkelingsbehoeften stelde, werden bedrijven gedwongen naar andere vestigingsplaatsen uit te zien. In het merendeel van de gevallen was er evenwel ter plaatse voldoende ontwikkelingsruimte aanwezig en werd de dynamiek ter plaatse ruimtelijk aanvaard.

Zonevreemdheid ten aanzien van een gewestplan kan dus gedefinieerd worden als zijnde een gebouw, activiteit of functie waarbij de juridische toets een strijdigheid met bestaande voorschriften (de bestaanbaarheidsvereiste) aangeeft, ofwel waarbij de planologische toets een onverenigbaarheid met de bestaande aanwezige activiteiten en functies (de verenigbaarheidsvereiste) daartoe besluit.

Vanuit die dubbele vereiste is zonevreemdheid een moeilijk te vatten algemeen begrip. Het heeft een juridische dimensie ten aanzien van de voorschriften van het gewestplan; het heeft ook een afwegingsdimensie, enerzijds vanuit de activiteit of functie zelf, anderzijds vanuit de relatie ten opzichte van de omgeving. Zowel binnen de vergunningverlening als binnen de planningscontext moet die afweging gebeuren rekening houdend met de grenzen die door de decreetgever zijn aangereikt. En die zijn verschillend. Vergunningen worden verleend binnen de enge context van de ruimtelijke ordening vastgelegd in de verordenende plannen van

Door die principes wordt één van de basisbeginselen van de stedenbouwwet toegepast. De hiërarchie der plannen moet een noodzakelijke tempering vinden in soepelheid, zonder dewelke de ruimtelijke ordening een keurslijf wordt. In de zinsnede "desnoods afwijken" vindt die soepelheid zijn meest extreme vorm. Als regel moet de soepelheid tot uiting komen in flexibele voorschriften van de plannen zelf en in de mogelijkheid de plannen te herzien en daaropvolgend te vervangen. Doch "desnoods" wint de soepelheid het op de hiërarchie.

De Raad voegt hieraan nog toe dat het voorstellen en goedkeuren van een B.P.A., dat afwijkt van een vroeger vastgesteld gewestplan, niet op wettige wijze kan geschieden, uitsluitend om vergissingen, anomalieën of onwettigheden begaan ten tijde van de totstandkoming van een gewestplan goed te maken, en ook niet om de gevolgen van een vernietiging van een gewestplan door de Raad van State te herstellen. 
aanleg. Bij de planning geldt een ruimere opdracht die voortvloeit uit de bepalingen van artikel 1 DRO. Plannen van aanleg worden immers ontworpen mede vanuit een economisch, sociaal en esthetisch oogpunt.

Individuele beslissingen, zowel in het kader van vergunningen als in het kader van planning, worden steeds moeilijker. Beleidsmatig wordt in Vlaanderen vanaf de jaren 93 gekozen voor een meer integrale benadering van de ruimtelijke problematiek. Exponenten van die beleidswil zijn het planningsdecreet van 1996, waarbij ruimtelijke visievorming op de drie bestuursniveaus decretaal verankerd wordt in de structuurplannen, en de vaststelling van het Ruimtelijke Structuurplan Vlaanderen (RSV) bij besluit van 23 september 1997 van de Vlaamse regering en het decreet van 17 december 1997 houdende bekrachtiging van de bindende bepalingen van het RSV. Ten aanzien van de zonevreemde problematiek wordt in het RSV een kader aangereikt. In afwachting dat het gemeentelijk ruimtelijk structuurplan beleidsuitspraken doet, heeft de Vlaamse regering in de omzendbrief RO/97/01, voor zonevreemde bedrijven een oplossing aangereikt via de opmaak van sectorale BPA 's.

\section{Zonevreemdheid en het huidig ruimtelijk ordeningsbeleid}

\subsection{Het Ruimtelijk Structuurplan Vlaanderen}

Over de ontwikkelings- en uitbreidingsmogelijkheden voor bestaande bedrijven buiten de bedrijventerreinen worden in het RSV de volgende principes naar voren geschoven ${ }^{9}$ :

Samengevat worden de volgende principes naar voren geschoven:

- Bestaande bedrijven (zowel zone-eigen als zonevreemd), die niet gelegen zijn op bestaande bedrijventerreinen, maken deel uit van de economische structuur.

- Ontwikkelingsperspectieven worden bepaald door de aard en het karakter van het bedrijf zelf en door de ruimtelijke draagkracht van de omgeving die door de gemeente voor de betrokken omgeving moet ingevuld worden.

- Schematische ontwikkelingsmogelijkheden voor de bedrijven buiten de bestaande bedrijventerreinen wordt in tabel 6 weergegeven.

- De gemeente krijgt de verantwoordelijkheid om de ontwikkelingsperspectieven van de bestaande bedrijven of economische activiteiten te formuleren op basis van haar verantwoordelijkheid ten aanzien van verlening en/of advisering van de milieuvergunning, haar kennis en inschatting van de plaatselijke toestand en de bepaling van de ruimtelijke draagkracht.

- Principes bij de beoordeling van ontwikkelings- en uitbreidingsmogelijkheden zijn:

- een maximale verweving van economische activiteiten met de activiteiten in haar (bebouwde of onbebouwde) omgeving wordt nagestreefd; goed nabuurschap moet het uitgangspunt vormen; voor het principe goed nabuurschap kan, net zoals voor het principe ruimtelijke draagkracht, geen algemeen geldende objectieve en meetbare maatstaven voor heel Vlaanderen worden aangereikt. Goed nabuurschap is afhankelijk van de ruimtelijke structuur, het ruimtelijk functioneren van een gebied, de gewenste ruimtelijke ontwikkeling van het gebied, de aard van het bedrijf en haar activiteit. De gemeente zal goed nabuurschap voor de betrokken omgeving kwalitatief moeten bepalen. 
- alle mogelijkheden en voorzieningen (op milieuhygiënisch vlak, qua mobiliteitsproblematiek,...) voor ontwikkeling op de bestaande lokatie worden uitputtend aangewend;

- de ruimtelijke implicaties bij een herlokalisatie (bijkomende infrastructuur voor nieuwe lokale en regionale bedrijventerreinen, bijkomend ruimtegebruik, versnipperen van onbebouwde ruimte, verminderen van ontwikkelingsmogelijkheden voor natuur, landbouw en bos,...) worden afgewogen tegenover de ruimtelijke implicaties van een ontwikkeling op de bestaande lokatie;

- de ruimtelijke draagkracht van de omgeving mag niet worden overschreden; dit begrip is niet in algemene regels te vatten, maar het wordt gebied per gebied bepaald; historische gegroeide situaties en hinder zijn mede bepalend voor de draagkracht;

- er wordt ten aanzien van de ontwikkeling van de economische activiteit een maximale beleidszekerheid en beleidscontinuïteit nagestreefd zowel in ruimte als in tijd: de verwachte ontwikkeling en uitbreiding van het bedrijf moeten goed ingeschat worden evenals bedrijfseconomische implicaties (efficiëntere organisatie van de bedrijfsgebouwen, verbeterde ontsluiting,...) volgens het BATNEEC-principe.

Om de vermelde principes operationeel te maken is het noodzakelijk dat ook op gemeentelijk niveau ofwel een gemeentelijk ruimtelijk structuurplan ofwel in afwachting daarvan een samenhangende visie op de lokale economie wordt uitgewerkt. De opbouw van deze visie gebeurt op basis van de analyse van de bestaande ruimtelijke economische structuur (met o.a. een inventaris van zonevreemde en door uitbreiding mogelijk zonevreemd wordende bedrijven).

De visie op de lokale economie en met name op de uitbreidings- en ontwikkelingsmogelijkheden kan effectief gemaakt worden in gewestelijke en provinciale ruimtelijke uitvoeringsplannen voor economische activiteiten met een bovenlokale reikwijdte en in gemeentelijke ruimtelijke uitvoeringsplannen voor lokale bedrijven.

Een gemeentelijk ruimtelijk uitvoeringsplan waarin het volledige grondgebied of voor een deel van het grondgebied wordt aangegeven wat de uitbreidingsmogelijkheden voor de aldaar gevestigde bedrijven zijn, is voor de gemeente een mogelijk instrument (het zogenaamde "sectorale B.P.A "). Het ruimtelijk uitvoeringsplan kan betrekking hebben op zowel zonevreemde bedrijven als zone-eigen bedrijven die wensen uit te breiden in een nietgeëigende bestemming. In het ruimtelijk uitvoeringsplan worden de uitbreidingsmogelijkheden van het bedrijf met specifieke verordenende voorschriften vastgelegd. Daarbij wordt aangetoond of er uitbreidingsmogelijkheden zijn en onder welke voorwaarden dat kan gebeuren. De afgebakende oppervlakte voor uitbreiding wordt opgenomen in de ruimtebalans tussen de vraag en aanbod voor bedrijventerrein voor de betrokken gemeente. 


\section{INVENTARISATIE VAN BESTAANDE BEDRIJVEN BUITEN BEDRIJVENTERREINEN lokaal bedrijf regionaal bedrijf}

\section{KADERING IN GEMEENTELIJK RUIMTELIJK STRUCTUURPLAN}

$\mathrm{I}^{\circ}$ analyse van de bestaande ruimtelijk-economische structuur

II $^{\circ}$ gemeentelijke visie op de ruimtelijke en de economische ontwikkeling

\section{RUIMTELIJKE ONTWIKKELINGSMOGELIJKHEDEN}

Ontwikkeling/uitbreiding mogelijk op bestaande lokatie

Ontwikkeling/uitbreiding niet mogelijk op bestaande lokatie $=$ herlokalisatie

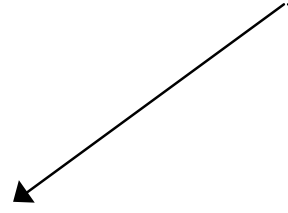

Binnen bestemming bestaand plan

van aanleg

- verweving

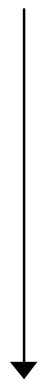

niet op te nemen

\section{JURIDISCHE INSTRUMENTEN}

Buiten bestemming bestaand plan

$$
\text { van aanleg }
$$

- opmaak sectoraal BPA

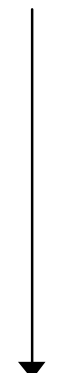

\section{EFFECT OP RUIMTEBALANS}

op te nemen

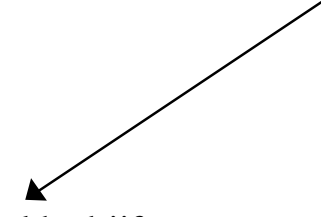

voor lokaal bedrijf

- lokaal bedrijventerrein via opmaak gemeentelijk ruimtelijk uitvoeringsplan

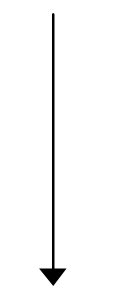

op te nemen

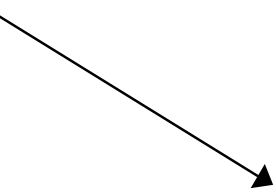

voor regionaal bedrijf

- bedrijventerrein voor historisch gegroeid bedrijf via gewestplan (Vlaanderen max 500ha, aansluitend bij kern/ bestaand bedrijf - op regionaal bedrijventerrein in economisch knooppunt

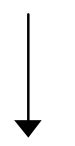

op te nemen 
Indien het bedrijf voldoende verweven is met andere functies en er geen specifieke ruimtelijke maatregelen noodzakelijk zijn (vb werkplaats,), wordt deze en eventuele uitbreiding niet opgenomen in het ruimtelijk uitvoeringsplan. In dit geval wordt de oppervlakte ingenomen door het bedrijf niet opgenomen in de ruimtebalans en betekent dit een stimulans voor verweving.

Het is noodzakelijk een inventaris op te maken voor alle zonevreemde bedrijven waaronder ook agrarische bedrijven. Deze lijst moet opgesteld worden op gemeentelijk schaalniveau op basis van de criteria opgesteld op Vlaams niveau. In dit verband kan de omzendbrief inzake de zonevreemde bedrijven (RO 97/01) als basis worden gebruikt. Daarbij is aandacht voor de tijdsdruk van de bedrijven gewenst en dient aandacht te worden besteed aan de specificiteit van de zonevreemde landbouwbedrijven.

Uit die bepalingen blijkt dat vanuit de opties van het RSV aan gemeenten een opdracht gegeven wordt naar zonevreemde bedrijven toe via hun eigen instrumentarium de ruimtelijke ontwikkelings-mogelijkheden te gaan vastleggen. Voor dringende problemen wordt hierbij het "sectorale B.P.A." als instrument aangereikt. Voor historisch gegroeide bedrijven, zijnde bedrijven met een regionale schaal, die morfologisch en ruimtelijk verweven zijn met de omgeving die een specifieke sociaal-economische relatie hebben met de omgeving, dient een initiatief door het gewest genomen te worden via de aanpassing van het gewestplan.

Het uitwerken van een visie op de lokale economie kan niet enkel op basis van een analyse van de gemeentelijke economie gebeuren; de economische positionering van een gemeente dient altijd te kaderen binnen een economische streekvisie. Die zijn er vaak niet zodat de wetenschappelijke (economische) onderbouwing van een visie op de lokale economie vaak te wensen overlaat. Daarenboven is er tot op heden weinig consistentie te vinden tussen de economische streekvisies en is er ook op niveau van het Vlaams Gewest geen integrerende visie op de economie van Vlaanderen, die een kader zou bieden waar de streekvisies kunnen ingepast worden. Deze lacunes worden al te vaak over het hoofd gezien waardoor de in opbouw zijnde gemeentelijke ruimtelijke structuurplannen op economisch vlak niks voorstellen.

\subsection{Dimensies in de bestuurlijke praktijk - omzendbrieven RO 93/1 en 97/01}

In afwachting dat in het gemeentelijk structuurplan een algemene visie ontwikkeld wordt biedt de omzendbrief RO 97/01 een algemeen kader voor de benadering van de problematiek van de zonevreemde bedrijven. Op basis van die omzendbrief kunnen een aantal essentiële elementen als volgt samengevat worden:

Het algemeen kader is de omzendbrief RO/93/1 van 10 november 1993:

- overschakeling van zachte naar harde functies met omzichtigheid;

- uitbreiding van bestaande vergunde constructies; geen vervanging;

- ongeschikte kunnen niet vervangen worden;

- globale benadering voor de gemeente of kern;

- behandeling t.a.v. de ruimtelijke problematiek van het gewestplan;

- globale inventarisatie van de bedrijven;

- niet meer dan $5 \mathrm{ha}$; anders gewestplan.

De opmaak van het BPA vereist de volgende stappen: 
- beslissing door de gemeente tot opmaak BPA;

- inventaris van alle zonevreemde bedrijven of zonevreemde uitbreidingen;

- overzicht van de bestaande juridische toestand, nl. vergunningen;

- de formulering van de gemeentelijke ruimtelijke visie binnen de principes van het RSV;

- de ontwikkelingsperspectieven van de verschillende bedrijven volgens categorieën ${ }^{10}$;

- opmaak van het sectoraal BPA.

\subsection{Evaluatie}

Aldus lijkt zowel vanuit het RSV als vanuit de bestuurlijke praktijk, vertolkt in de omzendbrief, een formeel kader afgebakend te zijn voor het oplossen van de problematiek van de zonevreemde bedrijven. In de praktijk zijn er evenwel teveel grenzen aan de aangereikte instrumenten. In de hiernavolgende paragrafen zullen we die grenzen proberen te duiden.

Er zijn juridische grenzen aan de geboden oplossingen. Het uitgewerkte voorstel, zowel in het RSV als in de omzendbrief blijft op dit ogenblik botsen met de bestaande regelgeving met betrekking tot van het gewestplan afwijkende BPA's. Juridisch is het afwijkende BPA een wankel instrument, waarvan sterk mag getwijfeld worden of het de toets van betwistingen voor de Raad van State zal doorstaan. Maar ook historisch gegroeide bedrijven via gewestplanwijzigingen oplossingen geven past eigenlijk niet binnen de finaliteit van een op het gewestelijk niveau te hanteren planningsinstrument.

Er zijn ook inhoudelijke grenzen aan het instrument. De louter ruimtelijke benadering botst met de sociaal-economische realiteit: er is reeds gewezen op de noodzaak om de problematiek van de zonevreemde bedrijven vanuit een geïntegreerde ruimtelijk én economische te benaderen. Het immens economisch gewicht van deze bedrijven dwingt economen en planners om samen tot ruimtelijk wenselijke en tezelfdertijd bedrijfsvriendelijke oplossingen te komen. Het aantrekkelijk maken van de herlokalisatie-optie zal bedrijven ertoe aanzetten herlokalisatie bespreekbaar te maken. De volgende principes en maatregelen kunnen gehanteerd worden om de keuze tussen herlokalisatie en uitbreiding bedrijfsvriendelijk te maken:

- Vergelijk economische netto-kosten tussen herlokalisatie en uitbreiding ter plaatse;

- Ga na wat de maatschappelijke/economische waarde is van de herbestemming van de bestaande lokatie;

- Garandeer de beschikbaarheid van lokale en regionale bedrijventerreinen binnen de straal van $15 \mathrm{~km}$;

- Haal de geherlokaliseerde zonevreemde bedrijven uit de ruimtebalansen. Het RSV is op dit vlak inconsistent omdat een herlokaliserend bedrijf gemiddeld drie tot vier keer zoveel ruimte aanvraagt als de bestaande zonevreemde lokatie. De huidige verrekening van subregionale beleidsmakers een motief om zoveel mogelijk

- Mak maximaal gebruik van de spontane herlokalisatie van bedrijven: d.w.z. dat de zonevreemde bedrijven problematiek dient te kaderen in een lange termijn strategie.

10 Cat. 1: bedrijven die niet mogen uitbreiden - bij stopzetting geen nieuwe zonevreemde activiteiten; Cat. 2: bedrijven met beperkte ( 10 à $25 \%$ ) uitbreidingsmogelijkheden; beperkingen voor de activiteiten; Cat. 3: bedrijven met beperkte (10 à 25\%) uitbreidingsmogelijkheden; geen beperkingen voor de activiteiten;

Cat. 4: bedrijven die verder kunnen ontwikkelen; beperking van de activiteiten;

Cat. 5: bedrijven die verder kunnen ontwikkelen; geen beperking van de activiteiten; 
- Verzeker bedrijfscontinuïteit door met de te herlokaliseren bedrijven lange termijn afspraken te maken. Dergelijke afspraken maken het mogelijk om het ruimtelijke ordening bedrijfsvriendelijk te maken, wat op zijn beurt weer het voordeel heeft dat er minder betwistingen zullen zijn en dat er minder naar de Raad van Staten gestapt zal worden om Ministeriële Besluiten te laten vernietigen;

- Mak een fonds voor te herlokaliseren bedrijven via de meerwaarde van verlaten zonevreemde bedrijvensites (vooral dan in woonzones) en roep expansiesteun in voor herlokaliserende bedrijven;

- De overheid dient te zoeken naar een pragmatische oplossing voor zonevreemde bedrijven die niet in orde zijn met bouwvergunningen. Bouwovertredingen zijn nooit goed te praten maar het Bestraffen "van overtredingen in de jaren tachtig of vroeger met criteria uit de jaren negentig getuigt ook niet van maatschappelijke rechtvaardigheid, temeer de overheid zelf schuld heeft aan de laissez-faire attitude in het verleden.

Er is de micro-realiteit van het ruimtelijk probleem van de zonevreemdheid die niet te verzoenen is met de geclaimde globale benadering binnen een macro-ruimtelijke visievorming. Ten slotte is er de verkokerde probleembenadering waarbij een opdeling van de economische realiteit in probleemvelden niet overeenstemt met de werkelijkheid. De inhoudelijke invulling van de aangereikte instrumenten is algemeen en niet vertaalbaar naar specifieke situaties. De afwegingscriteria zijn wollig in hun formulering en niet objectief invulbaar.

Tenslotte zijn er organisatorisch-bestuurlijke grenzen aan het instrument. Gemeenten worden geconfronteerd met een capaciteitsprobleem. De problematiek van de zonevreemdheid is een omvangrijke problematiek. Gemeenten moeten werken binnen een bestuurlijke context die niet aangepast is aan het opnemen van verantwoordelijkheden. Subsidiariteit wordt uitgehold door de bemoeizucht en inhoudelijke inmenging van de toezichthoudende overheid. Het is die onzekerheid ten aanzien van de appreciatie bij de goedkeuring door de hogere overheid die gemeenten doet aarzelen om het instrument te hanteren.

\section{Case : Het Wingense sectoraal BPA}

Tot op heden (januari 1999) zijn er slechts twee sectorale BPA voor zonevreemde bedrijven (gemeenten Wingene en Zwevegem) per Ministerieel Besluit goedgekeurd. Volgens de Administratie Ruimtelijke Planning zijn er nog 18 BPAs in voorontwerp (9 West-Vlaamse, 3 Oost-Vlaamse, 1 Limburgs en 5 Vlaams-Brabantse). Samen zijn die goed voor zowat 165 zonevreemde bedrijven. In wat volgt bespreken we het Wingense sectoraal BPA dat bij besluit van 24 juli 1998 van de Vlaamse minister bevoegd voor Ruimtelijke Ordening voor zonevreemde bedrijven slechts gedeeltelijk werd goedgekeurd. Het BPA is een interessante case om na te gaan hoe de structuurplanning, ondanks alle mooie ruimtelijke principes, er niet in slaagt om een onderbouwde oplossing te bieden voor een concreet en complex, socioeconomisch en ruimtelijk probleem.

Van de 29 aanvragen zijn er in dit BPA slechts 20 goedgekeurd. De andere negen zijn afgekeurd ondanks de unanieme lokale consensus die er rond het voorstel bestond. Zowel de gemeente, de regionale commissie voor advies als de bestendige deputatie hadden het dossier gunstig beoordeeld. De negen geweigerde bedrijven vertegenwoordigen een omzet van 2,3 miljard en 227 arbeidsplaatsen. Van de 29 aanvragen opgenomen in het voorstel van de gemeente is dit $35 \%$ van de omzet en $52 \%$ van de tewerkstelling. Naar ruimtebeslag nemen de 
geweigerde bedrijven reeds 15,8 ha in. Ze vroegen 6,2 ha uitbreiding. De twintig goedgekeurde bedrijven hebben reeds een ingenomen oppervlakte van 11,3 ha en hebben 5,2 ha uitbreiding gekregen. De totaal aangevraagde ruimte voor uitbreiding bedroeg $0.17 \%$ van het totale oppervlak van de gemeente Wingene.

\subsection{Algemene opvatting van het BPA}

Uit de samenstellende documenten van het BPA blijkt overduidelijk dat Wingene gefungeerd heeft als piloot in de aanpak van de zonevreemde problematiek. Noch de overheid noch de ontwerpers blijken een duidelijk zicht te zijn op de manier van aanpak. Algemeen valt op dat de gemeente de wil getoond heeft om een degelijk document uit te werken uitgaande van de door haar scherp aangevoelde problematiek rond de zonevreemdheid. De overheid, meer bepaald de Vlaamse administratie, heeft de case Wingene "niet aangegrepen om vanuit een oplossingsgerichte houding mee te werken aan het besluitvormingsproces. Men zou kunnen spreken van "pleinvrees" bij de administratie; zij durft of kan zich niet in een open denkproces met de gemeentelijke overheid engageren om tot een adequaat besluitvormingsproces te komen. Daarenboven heeft zij moeilijkheden om principes en theoretische concepten bij realisaties op het terrein vertaald te krijgen. Door de overheersende idee van een sturende rol voor de ruimtelijke ordening vanuit een conceptuele benadering heeft de administratie nauwelijks voeling met wat aan de basis leeft. Dergelijke houding dreigt een zelfvernietigende dimensie te krijgen.

De schets van de ruimtelijke problematiek van de zonevreemdheid gebeurt op een traditionele, beschrijvende wijze, kernachtig gestoffeerd en met een historisch perspectief. Het BPA kampt evenwel met het probleem om de ruimtelijke betekenis van de zonevreemdheid echt te visualiseren. Er zijn voldoende data beschikbaar, in lijsten en samengevat in overzichtstabellen. Wat deze cijfers echter naar de ruimtelijke dimensie toe betekenen is moeilijk detecteerbaar. De gedreven houding van de gemeente wordt vanuit die manier van probleemformulering onvoldoende ondersteund en onderbouwd. Daar waar al enige poging tot kaartmatige voorstelling van de ruimtelijke eigenheid van Wingene wordt uitgewerkt is het een uiteengerafeld beeld, in functie van bepaalde sectorale benaderingen (fragmentair voor het nederzettingspatroon, de open ruimte, de verkeersinfrastructuur, .).. De confrontatie met de ruimtelijke werkelijkheid van de zonevreemdheid komt onvoldoende over, noch per deelaspect, noch in het synthetiserend beeld. Wanneer daaraan een economische of sociale dimensie moet gekoppeld worden, wordt het beeld nog waziger. Bedrijfseconomische gegevens en tewerkstellingsgegevens krijgen geen ruimtelijke dimensie, waardoor hun betekenis in het kader van de ganse problematiek moeilijk interpreteerbaar wordt.

De indeling in categorieën geeft binnen de voorgaande optiek de indruk op een vrijblijvende wijze gebeurd te zijn. Ligt er een gebiedsgerichte benadering aan de basis van of spelen ook nog andere criteria een rol? Als principe is er een uitspraak. In welke mate de verschillende principes bij de indeling in categorieën effectief gehanteerd zijn en aanleiding hebben gegeven tot een of andere beslissing is niet meer zo duidelijk. Afwijkingen van de gestelde principes kunnen ons inziens zelfs aanvaardbaar zijn, op voorwaarde dat de afwijkende voorstellen vanuit hun specificiteit gemotiveerd worden.

Ook bij de selectie van de op te nemen bedrijven gaat het BPA uit van een eigen rationaliteit, die zich afzet tegen het kader zoals het door de hogere overheid wordt aangereikt. Het waarom ervan, de motieven van ruimtelijke, economische of sociale oorsprong die deze houding verantwoorden worden onvoldoende onderbouwd en in een motivering in de verf 
gezet. Het afwijkende karakter van het BPA is misschien best te illustreren aan het voorbeeld van de niet vergunde bedrijven die werden opgenomen in het BPA. De kritische houding van de administratie en het kabinet ten aanzien van deze problematiek is voldoende gekend. Het louter juridisch benaderen is onvoldoende om de overheid, waarvan men weet dat ze zeer kritisch tegenover dit aspect staat, over de brug te halen bij de goedkeuringsprocedure. Er is een inhoudelijke onderbouw nodig. Er is een diepgaande overweging naar haalbaarheid vanuit objectiveerbare en te onderbouwen elementen nodig. Deze zijn niet of onvoldoende terug te vinden: de te verwachten problemen en het gebrek aan discussieopenheid zijn een stuk onderschat geweest. Hierdoor is de operationalisering van het voorbereidende veldwerk een stuk tekort geschoten. De koppeling en ondersteuning ervan naar een onderbouwde gedegen visie, uitgeschreven op een casus gerichte wijze en binnen een consequent gehanteerde logica komt onvoldoende tot uiting. Nogmaals, louter juridische argumenten, hoe waardevol ook, volstaan niet en moeten onderbouwd worden door inhoudelijke, feitelijke aspecten die behoren bij de ruimtelijke problematiek.

Perceelsordenend is er een zeer gedetailleerde uitwerking van de planopties gebeurd. Terug valt hierbij op dat deze uitwerking geschiedt vanuit een vertrouwd, algemeen patroon, met een relatief geringe afweging en invulling naar de plek die geordend wordt. Ondanks hun detaillering, zijn ze te algemeen om zich in te passen in een gedifferentieerde kwaliteitsgerichte benadering van de diverse ruimtelijke problemen van de bedrijfslokaties. Afstemming van de voorschriften op de indeling in categorieën is eigenlijk niet terug te vinden. Het verschil in de categorieën wordt finaal gereduceerd tot een louter kwantitatief probleem, alhoewel er ontegensprekelijk ook kwalitatieve aspecten moeten bij betrokken worden. Het veldwerk of de kennis van het terrein komen ons inziens onvoldoende op de voorgrond bij de voorgestelde oplossingen op het perceelsordenend niveau.

De gedifferentieerdheid van de zonevreemdheid, laat zich niet vatten in standaardoplossingen. Deze vaststelling moet meer tot uiting komen in het BPA; maar moet ook kansen krijgen om tot uiting te komen, zeker door de houding van de hogere overheid die zich genuanceerd kan opstellen tegenover een initiatief van de lagere overheid. Hier komen we bij het tweede luik van de analyse, met name de houding van die hogere overheid, en meer in het bijzonder de gewestelijke administratie, ten aanzien van het proces dat de gemeente doorlopen heeft en het product dat ze aflevert.

\subsection{Houding van de gewestelijke administratie.}

De methodiek van de sectorale benadering blijkt door de terughoudende, zuiver planologische en sturende opstelling van de administratie een methodiek te zijn die moeilijk de lokale verwevenheid en het belang van de huidige lokatie voor het bedrijf in een juist perspectief laat inschatten. De centrale overheid dwingt de ruimtelijke benadering van de bedrijfsproblemen op een gefragmenteerde wijze te benaderen. Daar waar het BPA een krachtig instrument kan zijn in het probleemoplossend veld waarvoor gemeenten geplaatst worden, holt de administratie de kracht ervan uit door de inhoudelijke beperkingen die ze aan probleembenadering oplegt. Deze benadering culmineert in de betekenis die de administratie geeft aan het begrip bedrijf" zoals het in de sectorale benadering mag gehanteerd worden. Door uitsluiting van iedere bijkomende dimensie (zoals handel, horeca, .) .of door inperking van de bedrijvigheid naar de connotatie Tokaal "(wat dergelijk begrip ook naar de ruimtelijke dimensie mag hebben) ontneemt de administratie de eigenlijke planningsdimensie die ze aan haar wettelijke instrumenten toebedeelt. Ze verengt het wettelijk instrumentarium door het toepassingsgebied ervan te gaan fractioneren. Ze ontneemt vanuit haar beperkende opstelling 
de kracht die ze het ruimtelijke planningsinitiatief moet geven. Ze ondergraaft de rol van het aanlegplan, een rol die zich finaal moet situeren in het behartigen van het algemeen belang. De versnippering, het zich vastklampen aan de op de agenda geplaatste problemen, zonder de moed of de durf te hebben binnen een ruimer perspectief met problemen om te gaan, laat vermoeden dat het eventueel mislukken van de nieuwe aanpak in de structuurplanning door sommigen binnen de administratie als een persoonlijke nederlaag zou ervaren worden. Door op doctrinaire wijze de ingeslagen weg te blijven bewandelen, vergeet men dat men ondertussen drama 's aanricht binnen probleemvelden die op korte termijn om een oplossing roepen. Door zich op doctrinaire wijze op te stellen kan men evenmin op lange termijn slagen, omdat men dreigt te verstrikken in de uitgewerkte systemen, die, als ze al ooit tot een oplossing komen, op dat ogenblik reeds hopeloos achter de maatschappelijke realiteit nahollen.

De adviesverlening van de administratie is wazig, intern inconsistent en komt laat van de grond. Pas in de eindfase durft de administratie zijn egelstelling te verlaten en slechts aarzelend komt ze tot een standpuntbepaling ten aanzien van de concrete gevallen. Ook dan nog stelt ze zich principieel op, binnen de eigen interpretatie van de zelf uitgevaardigde regels. Het denken in grote structuren en principes slaagt er niet in om te gaan met een complexe realiteit, die een gedifferentieerde benadering vereist, die de principes als principes respecteert, maar ze niet verheft tot onafwendbare dogma 's. De houding van de administratie kan enkel verklaard worden door de dwangidee dat het zelf uitgewerkte planningssysteem moet slagen. Ieder oplossend initiatief, dat pragmatisch, realistisch denkend, buiten die doctrinaire benadering een hand reikt aan de problemen in het veld is bedreigend voor de voor zichzelf afgebakende markt van planologen.

De opdracht die in het RSV aan de gemeenten gegeven wordt, wordt niet ernstig genomen. De centrale administratie blijft de vinger aan de pols houden in het particuliere dossier. Ligt daar haar opdracht binnen een subsidiariteitconcept? Is dat de finaliteit van de structuurplanning op Vlaams niveau? Zijn de particuliere dossiers dan toch nog steeds de enige manier waarop een beleid kan bewaakt en gevoerd worden? Ondanks de consensus die op het lokale vlak rond de dossiers bestaat, moet een centraal "gezag" zijn finale uitspraak dwars doorheen deze lokale consensus wringen. Met welke legitimatie oefenen zij die opdracht uit? Wat zijn de garanties dat er op dat niveau tot een objectievere en betere besluitvorming gekomen wordt? De marginale vergelijking van wat goedgekeurd wordt en van wat niet goedgekeurd wordt -er wordt enkel t.o.v. de uitgesloten bedrijven een argumentatie opgebouwd - laat niet zonder meer toe te besluiten dat de centrale besluitvorming sluitend en objectief is.

Inhoudelijk wordt nog vastgesteld dat in het RSV de verantwoordelijkheid voor het oplossen van de zonevreemde problematiek bij de gemeente ligt. Hierbij wordt er geen onderscheid gemaakt naar de schaal van het bedrijf. Immers de zonevreemde problematiek is een afweging of een bedrijf op zijn bestaande lokatie kan blijven of niet. Indien uit de analyse van alle elementen blijkt dat een bedrijf ter plaatse mag blijven, dan is het onbelangrijk of dit bedrijf een lokaal, dan wel een regionaal belang heeft. Het is immers enkel in geval dat de analyse leidt tot de conclusie dat het bedrijf ter plaatse niet kan blijven bestaan, dat in functie van de aard van het bedrijf, lokaal of regionaal, een aangepaste lokalisatieplaats zal dienen gevonden te worden. Pas bij herlokalisatie zal een lokaal bedrijf zich moeten vestigen op een lokaal bedrijventerrein, terwijl een regionaal bedrijf zal moeten uitwijken naar een regionaal bedrijventerrein. Maar op zich is de dimensie van een bedrijf geen reden tot uitsluiting uit het sectoraal BPA. In de motivering van het besluit wordt deze argumentatie evenwel aangewend. 
Ten aanzien van het behoorlijk vergund zijn van de bedrijven kan een gelijkaardige opmerking gemaakt worden. Ons inziens gaat het niet op om een bedrijf dat in één van zijn onderdelen aangetast is door een bouwovertreding, te gaan catalogeren als zijnde niet vergund. In de beschrijving van de bestaande toestand kan een onderscheid gemaakt worden in de onderdelen die over een regelmatige vergunning beschikken en die onderdelen die dat niet hebben. In de afweging of aan het bedrijf mogelijkheden geboden worden om zich ter plaatse verder te ontplooien kan aldus rekening gehouden worden met wat vergund en wat niet. Dit is een feitelijke afweging die geval per geval op motieven eigen aan de ruimtelijke ordening (en die van economische, sociale en esthetische aard zijn) zal dienen onderbouwd te worden. In die afweging dient men de eisen van algemeen belang, die door het aanlegplan behartigd worden, te plaatsen tegenover de voordelen die de overtreder met zijn overtreding heeft gerealiseerd. Het niet volledig vergund zijn van enig onderdeel van het bedrijf is geen voldoende reden is om het niet op te nemen in het BPA.

\subsection{Besluit}

Ons inziens wil ARP de vinger teveel aan de pols houden. De houding om individuele bedrijven een oplossing binnen het gewestplan te geven, strookt nog minder met de doelstellingen die ten grondslag aan de gewestplannen moeten liggen dan deze bij een BPA. Problemen van individuele bedrijven horen niet thuis in een gewestplan; dit moet zich op een hoger niveau begeven en niet willen perceelsordenend op te treden. Dergelijke houding zal finaal de ruimtelijke ordening in een louter procedureel, formeel debat duwen. In dergelijk debat heeft nog enkel de machtspositie die men heeft een belang en spelen elementen van goede ruimtelijke ordening - in de zin van een economisch, sociale en cultureel evenwichtige maatschappij - geen enkel rol meer. Door de houding van de centrale administratie, ondanks het vernieuwde discours rond de structuurplanning, dreigen we in dergelijke situatie af te glijden. Dit houdt onder meer in dat het machtscentrum terug naar de hogere overheid verlegd wordt. Het voordeel van de lokale gedragenheid en rechtstreekse controle, krijgt in dergelijk besluitvormingsproces steeds minder kansen.

\section{Conclusies}

Het is merkwaardig dat het huidig ruimtelijk ordeningsbeleid in Vlaanderen een formeel kader aanbiedt voor het oplossen van de problematiek van de zonevreemde bedrijven zonder ook maar enig idee te hebben van de economische impact van de ruimtelijke bepalingen. Over het aantal zonevreemde bedrijven is nauwelijks iets geweten en over de economische betekenis ervan tast men in het duister. Het handvol studies op sub-regionale schaal geven aan dat het economisch gewicht van de zonevreemde bedrijven immens is; Bij de meest voorzichtige schattingen komt men op 90.000 jobs uit, maar vermoedelijk is de tewerkstelling in de Vlaamse zonevreemde bedrijven nog een stuk groter. Het economisch belang van de zonevreemde bedrijven verplicht economen én ruimtelijke planners samen aan tafel te zitten: de oplossingen voor deze populatie van bedrijven moet beantwoorden aan ruimtelijke criteria maar moet tezelfdertijd bedrijfsvriendelijk zijn. Men kan geen ruimtelijke orde afdwingen door de economische dynamiek te fnuiken. De lat moet duidelijk hoger liggen: door socioeconomische objectieven in te lassen in de structuurplanning kan het ruimtelijk beleid een onmisbare schakel vormen in het economisch ontwikkelingsbeleid. De problematiek van de zonevreemde bedrijven illustreert hoe een maatschappelijk gegeven dat een belangrijk 
ruimtelijk probleem vormt alleen een afdoende oplossing kan krijgen wanneer er voldoende aandacht geschonken wordt aan de sociale en economische aspecten van dit fenomeen.

Oplossingen voor de juridische grenzen aan het aangereikte instrument moeten dringend geïmplementeerd worden. Ofwel moet er rekening gehouden worden met de gewijzigde beleidscontext waarbinnen sectorale BPA's tot stand komen - waarbij een nieuwe invulling aan het begrip "desnoods afwijken" gegeven wordt -, ofwel moet er een decretaal initiatief genomen worden om de afwijkingsmogelijkheden van een BPA te regelen in overeenstemming met de intenties die ten grondslag liggen aan de omzendbrief RO 97/01 (dit kan bijvoorbeeld door het weglaten van het woordje desnoods', wanneer een BPA binnen een globale, sectorale benadering opgemaakt wordt).

De top down benadering van de ruimtelijke ontwikkelingen, geformuleerd vanuit principes zonder voldoende gedetailleerde kennis van de ruimtelijke realiteit, kan onvoldoende recht doen aan specifieke situaties die zich op het terrein voordoen. Dergelijke benadering moet dus getoetst kunnen worden aan de specifieke bottom-up informatie vanuit de lokale praktijk. Dit betekent dat er een adequaat en operationeel monitoringsysteem moet uitgebouwd worden dat de lokale besturen kunnen inzetten bij de behandeling van de problematiek. Het moet een actueel en inzetbaar systeem zijn. Het komt aan de centrale overheid toe hiervoor de nodige standaarden, in samenspraak met de lokale overheden, uit te werken. In geen geval is het de rol van de centrale overheid terug alles zelf te willen doen, omdat die opdracht niet behoort tot haar kerntaken.

Er moet ook worden afgestapt van de mythe dat alle overtredingen in de open ruimte een onbespreekbare hypotheek leggen op de spontaan ontstane ruimtelijke ontwikkelingen. Ook hier moet een gedifferentieerde benadering mogelijk blijven die het algemeen belang voor ogen heeft. Het kan niet dat de minste overtreding een onherroepelijke standstill of het verdwijnen van het bedrijf op zijn huidige lokatie tot gevolg heeft.

De overheid zal moeten afwegen wat de gevolgen zijn van het oriënteren van bedrijven naar daartoe bestemde gebieden. Er stelt zich een vraag naar de herbestemming van de verlaten site, die op een verantwoorde wijze zal moeten kunnen ingevuld worden. Het niet goedkeuren van een voorstel in een sectoraal BPA heeft niet alleen gevolgen naar het zonevreemde bedrijf, maar ook naar de ruimte die het inneemt. Niet beslissen lost de ruimtelijke problematiek niet op.

De meest prangende vraag blijft evenwel, hoe lang we het nog kunnen volhouden om ruimtelijke opdrachten door te spelen aan lagere overheden en terzelfdertijd deze overheden bij het nemen van de eindbeslissing over hun voorstellen, zonder schroom terug te fluiten. Centrale besluitvorming blijft in Vlaanderen primeren op de lokale; wat in de lokale planning uitgewerkt wordt moet wijken voor uitspraken over die lokale planning op het hogere niveau. De centrale Vlaamse overheid vertoont een manifest wantrouwen ten opzichte van de lokale overheid, zelfs al is het initiatief dat de lokale overheid neemt een opdracht die haar vanuit het centrum opgedragen is. We raken hier aan het fundament dat aan het planningssysteem in Vlaanderen. Het dossier "zonevreemde bedrijven" toont aan dat het kiemen in zich draagt om te verworden tot een onwerkzaam bureaucratisch systeem, dat gedirigeerd wordt vanuit traditionele machtscentra. In sectie 3.1 is aangetoond dat de economische differentiatie tussen sub-regio's zo groot is dat een streekgebonden aanpak zich opdringt; het erkennen van de economische specificiteit van iedere sub-regio is één van de basispremissen van waaruit het economisch beleid en het ruimtelijk ordeningsbeleid zouden moeten vertrekken. Het erkennen 
van deze specificiteit houdt ook in dat lagere overheden volwaardige partners zijn binnen de ruimtelijke planning.

Moderne systemen moeten uitgaan van overleg, verantwoordelijkheidszin, wederzijds respect, subsidiariteit, hetgeen doorvertaald naar planning toe, betekent dat ieder niveau op een autonome wijze aan beleidsvorming kan doen, zonder procedureel of reglementair zwaar uitgewerkte regels. Beleid van verschillende niveaus moet complementair zijn. Dergelijke complementariteit kan niet afgedwongen worden vanuit één niveau, maar vereist een wederzijdse mogelijkheid tot inbreng en bevruchting. Daarom is het noodzakelijk dat de verschillende overheden de reële kans krijgen om ieder binnen hun niveau en voor hun bevoegdheidsgebied hun visie ten aanzien van hun ruimtelijke ordening te formuleren. Het is vanuit die autonome beleidsformulering dat overheden met elkaar in overleg kunnen gaan en kunnen werken naar een consensus rond de operationele vertaling in de bestemmingsplannen die instrumenten, gericht op uitvoering zijn. Binnen de huidige opvatting van planning moet een lagere overheid zich inpassen in de boven haar vastgestelde regels. Enkel binnen de daar zeer gedetailleerd vastgelegde krijtlijnen kan een lagere overheid nog enig gedifferentieerd denkwerk rond haar ruimtelijke situatie uitvoeren. De gegeven marges zijn evenwel onvoldoende om vanuit de specificiteit van haar ruimtelijke situatie een door haar gedragen visie te ontwikkelen. Nochtans is het enkel vanuit dergelijk autonoom ontwikkelde visie dat een overleg op basis van gelijkwaardigheid met de overige partners kan tot stand komen en dat gewerkt kan worden aan een meer maatschappelijk gedragen beleid.

De betekenis en rol van de planning moet gestalte krijgen door de wijze waarop ieder niveau erin slaagt zijn beleidsvisie te formuleren en door de rol die het niveau te vervullen heeft bij de ten uitvoerlegging van het beleid. Op dat moment zal het eigen voorgestane beleid de toets van de uitvoering moeten doorstaan en aldus zijn geloofwaardigheid en conformiteit met de maatschappelijke realiteit moeten bewijzen. Een beleidsvisie die zich niet heeft ingepast in het breed maatschappelijk denken zal er niet in slagen zich op het terrein te realiseren en zal vanuit zijn conflictuele opstelling onuitvoerbaar blijken te zijn. Aldus is er mogelijkheid door een samenspel en wederzijdse betrokkenheid, te komen tot een zichzelf regulerend beleidsvormingsproces dat nauw aansluiting zal vinden met de maatschappelijke verwachtingen. Dergelijk systeem heeft het voordeel dat het meer vanuit een democratische controle gestuurd wordt, eerder dan vanuit een ambtelijk-bureaucratische controle. Door de democratische controle blijft het beheersbaar en behoudt het de aansluiting bij de socioeconomische en maatschappelijke realiteit.

De besluitvormingsprocessen binnen de ruimtelijke ordening moeten uitgaan van een aantal fundamenteel andere basisprincipes dan deze die thans gehanteerd worden. Zij moeten aansluiten bij de hogervermelde leidinggevende elementen en als resultaat daarvan hun vertolking vinden in:

- autonome, eigen beleidsformulering op de verschillende niveaus, zonder hiërarchische band en zonder harde rechtsgevolgen ten aanzien van de beleidsformulering van de andere niveaus -overleg en inbedding in een open besluitvormingsproces moet de band smeden en de consistentie ontwikkelen ten aanzien van gedifferentieerde maatschappelijke verwachtingen;

- bestemmingsplannen, die de burger binden, komen tot stand op het laagst mogelijke niveau, met name de gemeente, in uitvoering van het geformuleerde beleid; ze worden onderworpen aan goedkeuring van hogere niveau die enkel vanuit haar eigen beleidsbevoegdheden kan optreden; 
- flexibiliteit vanuit de vaststelling dat een maatschappij niet maakbaar is en snel evolueert; het evenwicht met de rechtszekerheid vereist een afgewogen specifiek besluitvormingsproces dat relateert naar de hogere beleidsformulering en van daaruit zijn legitimiteit put;

\section{Bibliografie}

Musyck, Bernard (1995); 'Autonomous industrialization in South West Flanders (Belgium): Continuity and Transformation ", Regional Studies, Vol 29.7, pp. 619-633.

Sociaal-Economische Raad van Vlaanderen (1998a); Een sociaal-economische aftasting van probleemvelden in verband met het ruimtelijk structuurplan Vlaanderen, de bestaande uitvoeringsinstrumenten en de problematiek van zonevreemde bedrijven. Invulling van de ruimtelijke accenten in het kaderakkoord werkgelegenheid van de sociale partners van 17 november 1997 , SERV-Brussel.

Sociaal-Economische Raad van Vlaanderen (1998b); Evaluatiedossier : het ruimtelijk structuurplan Vlaanderen; de bestaande uitvoeringsinstrumenten; de problematiek van zonevreemde bedrijven. Ter voorbereiding van de invulling van de ruimtelijke accenten in het kaderakkoord werkgelegenheid van de sociale partners van 17 november 1997 , SERV-Brussel.

Scheers, J. en F. Meuris (1997) Zonevreemde bebouwing in de arrondissementen Roeselare, Tielt en Kortrijk, Studie in opdracht van het Ministerie van de Vlaamse Gemeenschap, AROHM - Afdeling Ruimtelijke Planning.

Ruimtelijk Structuurplan Vlaanderen (1998); Ruimtelijk Structuurplan Vlaanderen: Integrale versie, Ministerie van de Vlaamse Gemeenschap : Brussel, 594 p..

Vanhaverbeke, Wim et al. (1993); Het economisch profiel van de Vlaamse stadsgewesten, KUL - ISRO, Leuven, 319 p.

Vanhaverbeke, Wim (1997a); "Het belang van zonevreemde bedrijven: een pilootstudie voor de arrondissementen Roeselare en Tielt", Economisch en Sociaal Tijdschrift, 51 ste jaargang, nr. 3, September, pp. 499-526.

Vanhaverbeke, Wim (1997b); Streekvisie voor de regio Kortrijk, In opdracht van REBAK, Maastricht / Kortrijk, 112 p.

Vanhaverbeke, Wim (1998); Het belang van zonevreemde bedrijven: Een inventarisatie voor het arrondissement Dendermonde, NIBOR / Universiteit Maastricht, Ontwikkeling Waas en Dender, 32 p. 